\title{
Clinical profile and outcome of Wilson disease in Indian children: A single centre study
}

\author{
Sandesh Kini ${ }^{1}$, Koushik Handattu ${ }^{1}$, Kalyan Chakravarthy Konda ${ }^{2}$, ${ }^{*}$ amesh Bhat $\mathbf{Y}^{3}$
}

Sri Lanka Journal of Child Health, 2019; 48(2): 134-139

\begin{abstract}
Background: Wilson disease is an inherited disorder of copper metabolism characterised by cirrhosis of the liver, bilateral degeneration of basal ganglia and pigmented rings in the periphery of cornea. The clinical features vary considerably. Early diagnosis and prompt treatment favours good prognosis.
\end{abstract}

Objectives: To study the clinical and biochemical features of children with Wilson disease and the outcome after therapy at one year follow up.

Method: The study was carried out at a tertiary care centre in South India. From January 2001 to December 2017, 35 children were diagnosed with Wilson disease based on clinical findings along with two or more of the following criteria: low serum caeruloplasmin level, increased urinary copper concentration before or after penicillamine challenge and/or the presence of Kayser-Fleischer (KF) rings.

Results: Presentation was hepatic in 18 (51.4\%), neurological in $8(22.9 \%)$, mixed hepatic and neurological in $3(8.6 \%)$ and pre-symptomatic in 6 (17.1\%). All 35 children had low serum caeruloplasmin (mean $9.29 \pm 5.37 \mathrm{mg} / \mathrm{dl}$ ) and elevated urinary copper (mean 172.8 \pm 118.8 $\mu \mathrm{g} / 24 \mathrm{hr})$. KF rings were seen in $16(45.7 \%)$. The Ferenci score ranged from 3 to 8 (median 4 ). Zinc was started in $33(94.3 \%)$ patients and penicillamine in $29(82.9 \%)$ Three patients died within 2 months of diagnosis, all having hepatic presentation. About 32 children were followed up for a mean duration of 5.42 years. Among children with hepatic presentation $11(61 \%)$ improved fully following treatment. Among children with neurologic onset 4

\footnotetext{
${ }^{1}$ Assistant Professor, ${ }^{2}$ Senior Resident, ${ }^{3}$ Professor, Department of Paediatrics, Kasturba Medical College, Manipal, Manipal Academy of Higher Education, 576104, Karnataka, India

*Correspondence: ramesh.bhaty@manipal.edu

iD https://orcid.org/0000-0003-2919-6361

(Received on 18 May 2018: Accepted after revision on 20 July 2018)

The authors declare that there are no conflicts of interest Personal funding was used for the project.
}

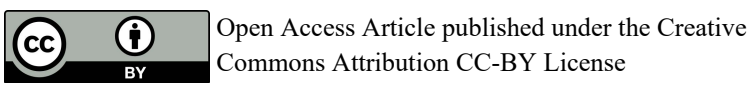

$(50 \%)$ showed significant improvement, while the rest had persistent neurological deficits.

Conclusions: In this study, presentation of Wilson disease was hepatic in $51.4 \%$, neurologic in $22.8 \%$, mixed hepatic and neurological in $8.6 \%$ and presymptomatic in $17.2 \%$. Hepatic presentations had more mortality while neurological presentations had persistent abnormalities

DOI: http://dx.doi.org/10.4038/sljch.v48i2.8706

(Key words: Wilson disease, children, Ferenci Score, King's Wilson index, sibling screen)

\section{Introduction}

Wilson disease is caused by mutations in the ATP7B gene leading to toxic accumulation of copper in the liver, nervous system, cornea, kidneys and heart ${ }^{1}$. Diagnosis is sometimes difficult and a scoring system can be useful. Ferenci scoring system has a sensitivity of $98.1 \%$ and a specificity of $96.6 \%$ in the diagnosis of Wilson disease ${ }^{2}$.

\section{Objectives}

To study the clinical profile of children with Wilson disease and the outcome following therapy.

\section{Method}

A retrospective review was done of the files of 35 children presenting to our paediatric unit between January 2001 and December 2017, with a diagnosis of Wilson disease. An approval from Institutional ethics committee was obtained for the study (IEC: 146/2018). The diagnosis of Wilson disease was based on presence of liver disease or neurological manifestations and a minimum of two of the following criteria:

1. Wilson disease among first degree relatives.

2. Low serum caeruloplasmin $(<20 \mathrm{mg} / \mathrm{dl})$

3. Elevated baseline 24-hour urine copper ( $>40 \mu \mathrm{g} / 24$ hours),

4. Raised 24-hour urine copper excretion after administering two 500-mg doses of penicillamine ( $>200 \mu \mathrm{g} / 24$ hours),

5. Presence of Kayser-Fleischer (KF) rings

6. Coomb's negative haemolytic anaemia.

Children having hepatitis $\mathrm{B}$, hepatitis $\mathrm{C}$ or autoimmune hepatitis were excluded from the study. 
Ferenci Score $^{2}$ was calculated for each of the patients. Siblings of index cases were screened for Wilson disease. Patients with hepatic forms were treated with oral Zinc sulphate $(150 \mathrm{mg} /$ day) and/or D-penicillamine starting at an initial dose of 1 $10 \mathrm{mg} / \mathrm{kg} /$ day and gradually increased to $20 \mathrm{mg} / \mathrm{kg} /$ day. Patients with neurological forms received pyridoxine $(100 \mathrm{mg} /$ week and dose titrated as per response) in addition to zinc and Dpenicillamine. Patients were followed up every 3 to 6 months depending on the clinical condition. Side effects of therapy like skin rashes, gastritis etc. were closely monitored.

Outcome was measured in terms of free copper $[=$ serum copper in $\mu \mathrm{g} / \mathrm{dl}$ - $(3 \times$ caeruloplasmin in $\mathrm{mg} / \mathrm{dl})]$, urine copper and liver enzymes at one year follow up, time taken for normalisation of liver enzymes and clinical course of the disease. King Wilson's index as suggested by Dhawan et $\mathrm{al}^{3}$ was calculated for each patient to predict the outcome of hepatic decompensation in the setting of Wilson disease.

Statistical analysis was done using IBM SPSS statistics version 23. Results were expressed as mean, median, range, standard deviation and percentage.

\section{Results}

The 35 children diagnosed with Wilson disease were offspring of 32 couples. Five (15.6\%) couples were consanguineous. Symptomatic index cases were 29, three were asymptomatic with hepatomegaly incidentally detected on routine check-up and 3 were diagnosed during sibling screen. Males were 23 $(65.7 \%)$ and females were $12(34.3 \%)$. The clinical presentation is listed in Table 1, laboratory data in table 2 and ultrasound findings in table 3.

Table 1: Symptoms and signs at presentation

\begin{tabular}{|c|c|c|c|c|}
\hline Variable & $\begin{array}{c}\text { Hepatic } \\
(n=18)\end{array}$ & $\begin{array}{c}\text { Neurologic } \\
(n=8)\end{array}$ & $\begin{array}{c}\text { Mixed } \\
(n=3)\end{array}$ & $\begin{array}{l}\text { Pre-symptomatic } \\
(n=6)\end{array}$ \\
\hline Age at onset in years (median/range) & $11.5(8-16)$ & $11.7(6-13.9)$ & $09(4-12)$ & $12.2(9-16)$ \\
\hline Age at diagnosis in years (median/range) & $11.5(8-16)$ & $13.0(11.5-15.3)$ & $10.3(4-17)$ & $12.2(9-16)$ \\
\hline Male/female & $10 / 8$ & $5 / 3$ & $3 / 0$ & $5 / 1$ \\
\hline Consanguinity [n (\%)] & $03(16.7)$ & $0(0)$ & $02(66.7)$ & $0(0)$ \\
\hline Hepatomegaly [n (\%)] & $14(77.8)$ & $06(75.0)$ & $02(66.7)$ & $06(100.0)$ \\
\hline Splenomegaly [n (\%)] & $12(66.7)$ & $02(25.0)$ & $02(66.7)$ & $02(33.3)$ \\
\hline KF ring $[\mathrm{n}(\%)]$ & $10(55.6)$ & $03(37.5)$ & $02(66.7)$ & $01(16.7)$ \\
\hline Jaundice $[\mathrm{n}(\%)]$ & $09(50.0)$ & $0(0)$ & $01(33.3)$ & $0(0)$ \\
\hline Pedal oedema [n (\%)] & $08(44.4)$ & $0(0)$ & $01(33.3)$ & $0(0)$ \\
\hline Ascites $[\mathrm{n}(\%)]$ & $05(27.8)$ & $0(0)$ & $0(0)$ & $0(0)$ \\
\hline Haematemesis [n (\%)] & $03(16.7)$ & $0(0)$ & $0(0)$ & $0(0)$ \\
\hline Melaena [n (\%)] & $01(05.6)$ & $0(0)$ & $0(0)$ & $0(0)$ \\
\hline Decreased school performance [n (\%)] & $02(11.1)$ & $05(62.5)$ & $02(66.7)$ & $0(0)$ \\
\hline Dysarthria [n (\%)] & $0(0)$ & $02(25.0)$ & $02(66.7)$ & $0(0)$ \\
\hline Slurred speech [n (\%)] & $0(0)$ & $03(37.5)$ & $02(66.7)$ & $0(0)$ \\
\hline Abnormal gait [n (\%)] & $0(0)$ & $03(37.5)$ & $02(66.7)$ & $0(0)$ \\
\hline Behavioural problems [n (\%)] & $0(0)$ & $04(50.0)$ & $01(33.3)$ & $0(0)$ \\
\hline Tremors [n (\%)] & $0(0)$ & $02(25.0)$ & $01(33.3)$ & $0(0)$ \\
\hline Chorea $[\mathrm{n}(\%)]$ & $0(0)$ & $01(12.5)$ & $0(0)$ & $0(0)$ \\
\hline Seizures [n (\%)] & $0(0)$ & $02(25.0)$ & $0(0)$ & $0(0)$ \\
\hline Rigidity [n (\%)] & $0(0)$ & $07(87.5)$ & $03(100.0)$ & $0(0)$ \\
\hline Dystonia [n (\%)] & $0(0)$ & $02(25.0)$ & $01(33.3)$ & $0(0)$ \\
\hline
\end{tabular}

KF: Kayser-Fleischer, 
Table 2: Laboratory parameters at presentation

\begin{tabular}{|c|c|c|c|c|}
\hline Variable & $\begin{array}{l}\text { Hepatic }(n=18) \\
\text { median (range) }\end{array}$ & $\begin{array}{l}\text { Neurologic }(n=8) \\
\text { median (range) }\end{array}$ & $\begin{array}{c}\text { Mixed }(n=3) \\
\text { median (range) }\end{array}$ & $\begin{array}{c}\text { Pre-symptomatic } \\
(n=6) \\
\text { median (range) }\end{array}$ \\
\hline $\mathrm{Hb} \mathrm{g} / \mathrm{dl}$ & $10(7-15)$ & $12.3(10.4-13.7)$ & $13(13-13)$ & $12(10-14)$ \\
\hline Total WBC count per $\mu \mathrm{L}$ & $\begin{array}{c}6100 \\
(2200-17,200)\end{array}$ & $\begin{array}{c}8000 \\
(4300-10,400)\end{array}$ & $\begin{array}{c}6100 \\
(5800-9300)\end{array}$ & $\begin{array}{c}5100 \\
(2200-8100)\end{array}$ \\
\hline Platelet per $\mu \mathrm{L}$ & $\begin{array}{c}111,000 \\
(20,000-404,000)\end{array}$ & $\begin{array}{c}230,000 \\
(68,000-295,000)\end{array}$ & $\begin{array}{c}105,000 \\
(64,000-236,000)\end{array}$ & $\begin{array}{c}240,000 \\
(49,000-282,000)\end{array}$ \\
\hline $\mathrm{TB} \mathrm{mg} / \mathrm{dl}$ & $02(0.2-27)$ & $0.8(0.2-3.0)$ & $01(1-33)$ & $01(1-2)$ \\
\hline $\mathrm{DB} \mathrm{mg} / \mathrm{dl}$ & $01(0.1-21)$ & $0.2(0.1-1.5)$ & $0.3(0.3-23.3)$ & $0.16(0.2-1)$ \\
\hline Total protein $\mathrm{g} / \mathrm{dl}$ & $7(4-8)$ & $7.9(4.7-8.6)$ & $7(7-7)$ & $8(6-8)$ \\
\hline Albumin g/dl & $3(2-5)$ & $4.25(1.9-4.6)$ & $4(2-4)$ & $4(3.8-4.1)$ \\
\hline AST, IU/L & $91(11-982)$ & $24.5(19-63)$ & $39(29-618)$ & $27(20-125)$ \\
\hline ALT, IU/L & $57.5(8-1322)$ & $14.5(5-54)$ & $15(13-110)$ & $23.5(12-143)$ \\
\hline ALP, IU/L & $227(67-855)$ & $145(88-288)$ & $286(13-622)$ & $149(102-556)$ \\
\hline PT seconds & $19(12-120)$ & $14.4(12.1-31.7)$ & $23(12-27)$ & $13.5(12-18)$ \\
\hline INR & $1.5(1-9)$ & $0.95(0.8-2.23)$ & $1(1-1)$ & $1(0.8-1)$ \\
\hline Caeruloplasmin mg/dl & $12.5(1.8-18.7)$ & $13.5(3.3-18.6)$ & $5(5.2-13.8)$ & $17(8-18.5)$ \\
\hline Serum copper $\mu \mathrm{g} / \mathrm{dl}$ & $44.2(23-135)$ & $74.5(44.4-98)$ & $70.2(22-80)$ & $64.5(23-162)$ \\
\hline Free copper $\mu \mathrm{g} / \mathrm{dl}$ & $19.5(0-102)$ & $36.85(0-78)$ & $39(6-58)$ & $25.5(0-112)$ \\
\hline Basal urine $\mathrm{Cu} \mu \mathrm{g} / 24 \mathrm{hrs}$ & $247.5(56-1324)$ & $250.5(81-489)$ & $356(242-514)$ & $203.5(137-416)$ \\
\hline Ferenci score $^{1}$ & $4(2-6)$ & $4.5(2-8)$ & $2.5(2-6)$ & $8(2-8)$ \\
\hline King's Wilson index ${ }^{3}$ & $4(1-18)$ & $2(1-7)$ & $4(1-11)$ & $1(0-2)$ \\
\hline
\end{tabular}

TB: total bilirubin, DB: direct bilirubin, AST: aspartate transaminase, ALT: alanine transaminase, ALP: alkaline phosphatase, PT: prothrombin time, INR: international normalized ratio

Table 3: Ultrasound features at presentation $(n=35)$

\begin{tabular}{|l|c|c|c|c|}
\hline \multicolumn{1}{|c|}{ Variables } & $\begin{array}{c}\text { Hepatic } \\
(\boldsymbol{n}=\mathbf{1 8})\end{array}$ & $\begin{array}{c}\text { Neurologic } \\
(\mathbf{n = 8})\end{array}$ & $\begin{array}{c}\text { Mixed } \\
(\boldsymbol{n}=3)\end{array}$ & $\begin{array}{c}\text { Pre-symptomatic } \\
(\boldsymbol{n}=\mathbf{6})\end{array}$ \\
\hline Coarse liver echotexture [n (\%)] & $13(72.2)$ & $06(75)$ & $03(100)$ & $01(16.7)$ \\
\hline Surface nodularity [n (\%)] & $06(33.3)$ & $03(37.5)$ & $0(0)$ & $01(16.7)$ \\
\hline Portal Hypertension [n (\%)] & $05(27.8)$ & $0(0)$ & $0(0)$ & $01(16.7)$ \\
\hline Portal vein size [mm (median/range)] & $09(06-14)$ & $08.8(08.2-10)$ & $09(08-11)$ & $10.5(10-11)$ \\
\hline Features of cirrhosis [n (\%)] & $05(27.8)$ & $03(37.5)$ & $01(33.3)$ & $01(16.7)$ \\
\hline
\end{tabular}

\section{Characteristics of patients presenting with liver disease}

Four children presented with acute hepatitis, 11 with features of chronic liver disease and 3 with fulminant hepatic failure. The predominant symptoms were jaundice in $9(50 \%)$ (duration $<1$ month in 5, persistent jaundice between 3 to 6 months in 3 cases, intermittent jaundice since 2 years with episode at presentation less than one month duration in one patient), pedal oedema in 8 $(44.4 \%)$, ascites in $5(27.8 \%)$, haematemesis in 3 $(16.7 \%)$ and melaena in one $(5.6 \%)$.
Genetic tests were done in 3 children and mutations in the ATP7B gene were detected in one child (homozygous for stop codon replaces lysine at codon 910 [AAG $>$ TAG]). Two children underwent splenectomy within 2 years of presentation in view of portal hypertension. One child progressed to decompensated liver cell failure. One child had symptomatic refractory anaemia despite multiple blood transfusions and oral/intravenous iron on several occasions. The work up had revealed reticulocyte count of $2.7 \%$, c-ANCA weakly positive, normal vitamin B12 level and haemostatic 
screen with negative stool occult blood and parasites.

In this group $16(88.9 \%)$ received zinc, $14(77.8 \%)$ received penicillamine and $6(33.3 \%)$ received pyridoxine. Compliance to treatment was good in 12 $(66.7 \%)$ patients. The outcome at one year follow up is presented in table 4 .

Table 4: Laboratory parameters at one year follow up $(n=26)$

\begin{tabular}{|l|c|c|c|c|}
\hline \multicolumn{1}{|c|}{ Variable } & $\begin{array}{c}\text { Hepatic }(\boldsymbol{n}=14) \\
\text { median (range) }\end{array}$ & $\begin{array}{c}\text { Neurologic }(\boldsymbol{n}=5) \\
\text { median (range) }\end{array}$ & $\begin{array}{c}\text { Mixed }(\boldsymbol{n}=3) \\
\text { median (range) }\end{array}$ & $\begin{array}{c}\text { Pre-symptomatic }(\boldsymbol{n}=4) \\
\text { median }(\mathbf{r a n g e})\end{array}$ \\
\hline Free copper $\mu \mathrm{g} / \mathrm{dl}$ & $24(3-61)$ & $22(4-46)$ & $38(23-42)$ & $18(0-96)$ \\
\hline Urine copper $\mu \mathrm{g} / 24 \mathrm{hrs}$ & $200(25-705)$ & $201(45-1323)$ & $355(49-355)$ & $127(59-248)$ \\
\hline AST IU/L & $25.5(13-88)$ & $26(20-79)$ & $36(26-128)$ & $30(28-64)$ \\
\hline ALT IU/L & $18.5(11-66)$ & $18(10-27)$ & $14(11-102)$ & $19.5(18-32)$ \\
\hline Follow up period in years & $4.1(0-10.5)$ & $2.2(0.4-12.1)$ & $2.3(1.7-6.7)$ & $3.3(0-11.7)$ \\
\hline
\end{tabular}

AST: aspartate transaminase, ALT: alanine transaminase,

Elevation in AST was observed in 7 (38.8\%) and ALT in $6(33.3 \%)$ patients which normalised within a mean duration of $18.8 \pm 14.0$ months and $16 \pm 15.94$ months respectively following therapy. Three children died within two months of presentation. Two had hepatic encephalopathy and one had intraventricular haemorrhage secondary to grossly deranged liver function tests and coagulation parameters. Eleven children had good response to treatment and remained asymptomatic.

\section{Characteristics of patients presenting with neurological disease}

The predominant symptoms and signs were decreased school performance in $5(62.5 \%)$, dysarthria in $2(25 \%)$, drooling of saliva in $2(25 \%)$, slurred speech in $3(37.5 \%)$, abnormal gait in 3 $(37.5 \%)$, behavioural problems in $4(50 \%)$, seizures in $2(25 \%)$, tremors in $2(25 \%)$, chorea in one $(12.5 \%)$, rigidity in $7(87.5 \%)$ and dystonia in $2(25 \%)$

Genetic tests were done in two children of which mutation in the ATP7B gene was detected in one child (Homozygous for stop codon replaces lysine at codon 910 [AAG>TAG]. Another heterozygous substitution in codon 952 replaces lysine with arginine $[\mathrm{AAA}>\mathrm{AGA}])$.

In this group $8(100 \%)$ received zinc, $7(87.5 \%)$ received penicillamine and $7(87.5 \%)$ received pyridoxine. Only $4(50 \%)$ children were compliant with the treatment. Only 2 children had elevated AST and ALT at presentation, both of which normalised within a mean duration of 24.0 \pm 8.4 months and 12 months respectively following therapy. Good response with complete recovery of neuro-psychiatric manifestations was observed in 4 $(50 \%)$ children while $3(37.5 \%)$ had persistent neurological deficits
Characteristics of patients presenting with mixed hepatic and neurologic disease

The predominant symptoms and signs were jaundice in one $(33.3 \%)$, dysarthria in $2(66.7 \%)$, slurred speech in $2(66.7 \%)$, abnormal gait in $2(66.7 \%)$, rigidity in $3(100 \%)$ and dystonia in one $(33.3 \%)$. Genetic test was done in one child and no mutations were detected in the ATP7B gene. All 3 children received zinc, penicillamine and pyridoxine. One child had elevated AST and ALT at presentation both of which normalised by 48 months following initiation of therapy.

\section{Characteristics of pre-symptomatic patients}

These children were asymptomatic and were screened either in view of affected sibling or incidentally detected organomegaly. Hepatomegaly was found in $6(100 \%)$, splenomegaly in $2(33.3 \%)$ and $\mathrm{KF}$ ring in one $(16.7 \%)$. Six $(100 \%)$ children received zinc, $5(83.3 \%)$ received penicillamine and one $(16.7 \%)$ child received pyridoxine. One child had elevated AST and ALT at presentation, both of which normalised by 12 months following initiation of therapy.

There was no significant difference between age at onset, age at diagnosis, serum caeruloplasmin, free copper, basal urine copper, Ferenci score between the 4 groups at presentation. However King's Wilson index differed significantly between the 4 groups $(\mathrm{p}=0.04)$.

\section{Discussion}

There are limited data on Wilson disease that have exclusively described paediatric samples. Dhawan et $\mathrm{al}^{3}$ studied 88 children, El-Karaksy et al ${ }^{4}$ studied 54 children and Sintusek et $\mathrm{al}^{5}$ studied 21 children. Wilson disease may manifest anytime between 3 to 74 years $^{6}$. Mean age at diagnosis in our study was 11.3 years which is comparable to studies by Lin et $\mathrm{al}^{6}$ (13.2 years) and Rukunuzzaman et $\mathrm{al}^{7}$ (8.5 years). 
Male to female ratio of $2: 1$ in our study is similar to a large study from Bangladesh ${ }^{7}$.

The hepatic form of presentation is the most common and is often limited to elevated serum transaminases $^{7}$ and our study showed similar findings. Neurologic or psychiatric manifestations usually develop during the second or third decade but studies by Noureen et $a l^{8}$ and Kalra et $a l^{9}$ have reported earlier presentation in the first decade. KF rings were seen in $45.7 \%$ of the patients in our study whereas $66.3 \%$ of patients had KF ring in a study by Merle et $a l^{10}$ and was significantly higher in patients with neurologic presentation.

In children, the Ferenci score ${ }^{2}$ has a high sensitivity $(98.1 \%)$ and specificity $(96.59 \%)$ in the diagnosis of Wilson disease. A score of $0-1$ is unlikely, 2-3 is probable and $\geq 4$ is highly likely of Wilson disease and in our study the mean Ferenci score was 4.86 \pm 1.86 . In our study the mean serum caeruloplasmin was $9.29 \pm 5.37 \mathrm{mg} / \mathrm{dl}$. The threshold of serum caeruloplasmin $<14 \mathrm{mg} / \mathrm{dl}$ has a sensitivity and specificity of $93 \%$ and $100 \%$ respectively ${ }^{11}$ and values $<20 \mathrm{mg} / \mathrm{dl}$ have a sensitivity and specificity of $95 \%$ and $84.5 \%$ respectively $^{12}$ in the diagnosis of Wilson disease.

The mean free copper (non caeruloplasmin bound) in our study was $17 \pm 15.51 \mu \mathrm{g} / \mathrm{dl}$. In most untreated patients it will be more than $20 \mu \mathrm{g} / \mathrm{dl}^{13}$. The mean basal urine copper in our study was $172.86 \pm 118.85 \mu \mathrm{g} / 24$ hours. The basal urine copper cut off value of $40 \mu \mathrm{g} / 24$ hours has a sensitivity and specificity of $78.9 \%$ and $87.9 \%$ respectively ${ }^{12}$, whereas increasing the cut off value to $100 \mu \mathrm{g} / 24$ hours decreases the sensitivity to $65.8 \%{ }^{12}$ in the diagnosis of Wilson disease. In our study, post penicillamine challenge urine copper levels were assessed in 13 patients and the mean value was $985.86 \pm 643.33 \mu \mathrm{g} / 24$ hours. Considering the cut off value to be 5 times the upper limit of basal urinary copper values, the test has a sensitivity of $88 \%$ but a low specificity of $24.1 \%$ in the diagnosis of Wilson disease $^{12}$.

Three children in our study were diagnosed as Wilson's disease on sibling screening. Both American and European guidelines ${ }^{13,14}$ recommend screening of first degree relatives of patients with Wilson disease, as they have a $25 \%$ chance of being a homozygote and develop the clinical disease.

In our study Zinc was used as first line therapy. Dpenicillamine was added in most of the hepatic forms and pyridoxine in neurologic forms. All patients were advised a copper restricted diet. No adverse drug reactions were documented. Studies have shown that both Zinc sulphate and Dpenicillamine are effective as first line therapy in
Wilson disease and neither therapy is superior ${ }^{15}$. A good response to treatment is defined as when the serum transaminases return to normal ${ }^{16}$. In our study the median duration of normalisation of AST and ALT following therapy was 18 months and 12 months respectively. In a Brazilian study ${ }^{16}$ the median time taken to achieve a clinical response after starting D-penicillamine was 10.7 months.

The King's Wilson index (KWI) proposed by Dhawan et $\mathrm{al}^{3}$ is a useful marker to predict the outcome of children with hepatic decompensation. In our study, KWI was assessed for each of the patients and the mean value was $4.57 \pm 4.31$. Eleven points and above indicates urgent need for liver transplantation. The KWI has a sensitivity and specificity of $93 \%$ and $98 \%$ respectively and a positive predictive value of $93 \%{ }^{3}$.

The possibility of Wilson disease should be considered in any child more than one year old presenting with any form of liver disease ranging from asymptomatic with raised liver enzymes to decompensated cirrhosis. Appropriate evaluation and the Ferenci scoring system should be applied to make a diagnosis of Wilson disease. The King's Wilson index should be monitored for prognostication and timely referral for liver transplantation.

\section{Conclusions}

In this study, presentation of Wilson disease was hepatic in $51.4 \%$, neurologic in $22.8 \%$, mixed hepatic and neurological in $8.6 \%$ and presymptomatic in $17.2 \%$. Hepatic presentations had more mortality while neurological presentations had persistent abnormalities

\section{References}

1. Socha P, Janczyk W, Dhawan A, Baumann U, D'Antiga L, Tanner S, et al. Wilson Disease in children: A Position Paper by the Hepatology Committee of the European Society for Paediatric Gastroenterology, Hepatology and Nutrition. Journal of Pediatric Gastroenterology and Nutrition 2018; 66(2).

https://doi.org/10.1097/MPG.0000000000 001787

2. Dhawan A. Evaluation of the scoring system for the diagnosis of Wilson's disease in children. Liver International 2005; 25: 680-1.

https://doi.org/10.1111/j.1478-

3231.2005.01072.x

PMid: 15910506 
3. Dhawan A, Taylor RM, Cheeseman P, De Silva P, Katsiyiannakis L, Mieli-Vergani G. Wilson's disease in children: 37-year experience and revised King's for liver transplantation. Liver Transplant 2005; 11(4): 441-8.

https://doi.org/10.1002/lt.20352

PMid: 15776453

4. El-Karaksy H, Fahmy M, El-Raziky MS, El-Hawary M, El-Sayed R, El-Koofy N, etal. A clinical study of Wilson's disease: The experience of a single Egyptian Paediatric Hepatology Unit. Arab Journal of Gastroenterology 2011; 12(3):125-30. https://doi.org/10.1016/j.ajg.2011.07.007 PMid: 22055589

5. Sintusek P, Chongsrisawat V, Poovorawan Y. Wilson's disease in Thai children between 2000 and 2012 at King Chulalongkorn Memorial Hospital. Journal of the Medical Association of Thailand 2016; 99(2):182-7.

PMid: 27249898

6. Lin L-J, Wang D-X, Ding N-N, Lin Y, Jin $\mathrm{Y}$, Zheng C-Q. Comprehensive analysis on clinical features of Wilson's disease: An experience over 28 years with 133 cases. Neurological Research 2014; 36(2):15763.

https://doi.org/10.1179/1743132813Y.000 0000262

PMid: 24107488

7. Rukunuzzaman M. Wilson's Disease in Bangladeshi Children: Analysis of 100 Cases. Pediatric Gastroenterology, Hepatology and Nutrition 2015; 18(2):121. https://doi.org/10.5223/pghn.2015.18.2.12 1

PMid: 26157698 PMCid: PMC4493245

8. Noureen N, Rana MT. Neurological Wilson disease in children: a three year experience from Multan. Journal of the Pakistan Medical Association 2011; 61(8):743-8.

PMid: 22355993

9. Kalra V, Khurana D, Mittal R. Wilson's disease--early onset and lessons from a paediatric cohort in India. Indian Pediatrics 2000; 37(6):595-601.

PMid: 10869138
10. Merle U, Schaefer M, Ferenci P, Stremmel W. Clinical presentation, diagnosis and long-term outcome of Wilson's disease: A cohort study. Gut 2007; 56(1):115-20. https://doi.org/10.1136/gut.2005.087262 PMid: 16709660 PMCid: PMC1856673

11. Mak CM, Lam CW, Tam S. Diagnostic accuracy of serum caeruloplasmin in Wilson disease: Determination of sensitivity and specificity by ROC curve analysis among ATP7B- genotyped subjects. Clinical Chemistry 2008; 54(8): 1356-62.

https://doi.org/10.1373/clinchem.2008.103 432

PMid: 18556333

12. Nicastro E, Ranucci G, Vajro P, Vegnente A, Iorio R. Re-evaluation of the diagnostic criteria for Wilson disease in children with mild liver disease. Hepatology 2010; 52(6):1948-56.

https://doi.org/10.1002/hep.23910

PMid: 20967755

13. Easl. EASL Clinical Practice Guidelines: Wilson's disease. Journal of Hepatology 2012; 56(3):671-85.

https://doi.org/10.1016/j.jhep.2011.11.007 PMid: 22340672

14. Roberts EA, Schilsky ML. Diagnosis and treatment of Wilson disease: An update. Hepatology 2008; 47: 2089-111. https://doi.org/10.1002/hep.22261 PMid: 18506894

15. Czlonkowska A, Litwin T, Karliński M, Dziezyc K, Chabik G, Czerska M. Dpenicillamine versus zinc sulfate as firstline therapy for Wilson's disease. European Journal of Neurology 2014; 21(4):599-606.

https://doi.org/10.1111/ene.12348

PMid: 24447648

16. Sócio S de A, Ferreira AR, Fagundes EDT, Roquete ML V, Pimenta JR, Campos L de $\mathrm{F}$, et al. Wilson's disease in children and adolescents: diagnosis and treatment. Rev Paul Pediatr. 2010; 28(2):134-40. https://doi.org/10.1590/S01030582201000 0200002 